\title{
Spatio-temporal Distribution of Spawning and Stock Mixing of Atlantic Cod from the Northern Gulf of St. Lawrence and Southern Newfoundland Stocks on Burgeo Bank as Revealed by Maturity and Trace Elements of Otoliths
}

\author{
Red Méthot ${ }^{1}$, Martin Castonguay, Yvan Lambert \\ Pêches et Océans Canada, Institut Maurice-Lamontagne, C.P. 1000, Mont-Joli, Quebec, Canada G5H $3 Z 4$ \\ Céline Audet \\ Institut des Sciences de la Mer de Rimouski, Université du Québec à Rimouski, \\ 310 Allée des Ursulines, Rimouski, Quebec, Canada G5L 3A1 \\ and \\ Steven E. Campana \\ Fisheries and Oceans Canada, Bedford Institute of Oceanography, P.O. Box 1006, \\ Dartmouth, Nova Scotia, Canada B2Y 4A2

\begin{abstract}
Méthot, R., M. Castonguay, Y. Lambert, C. Audet, and S. E. Campana. 2005. Spatio-temporal and southern Newfoundland stocks on Burgeo Bank as revealed by maturity and trace elements of otoliths. J. Northw. Atl. Fish. Sci., 36: 31-42. doi: 10.2960/J.v36.m564.
\end{abstract} \\ distribution of spawning and stock mixing of Atlantic cod from the northern Gulf of St. Lawrence
}

\begin{abstract}
Atlantic cod (Gadus morhua) from the northern Gulf of St. Lawrence stock (NAFO Subdivisions 3Pn and Divisions 4RS) overwinter in deep waters east of Cabot Strait. During winter and spring, cod from this stock mix with fish from the southern Newfoundland cod stock (NAFO Subdiv. 3Ps), especially on Burgeo Bank. However, the degree and exact period of mixing are not known. The reproductive activity of female cod in the northern Gulf and on Burgeo Bank was examined to identify spawning areas, timing of reproduction, and stock mixing. From April to July 2001, spawning was studied visually ( $n=2129$ adult females) and histologically ( $n=450$ adult females) by following monthly changes in the frequency distributions of maturity stages of female cod. Spawning was more advanced in the northern Gulf than in the other areas in April. Few spawning females were caught during the study on Burgeo Bank, indicating that this region was not a major spawning area in spring 2001. The relative frequencies of fish in spawning condition in April and May were different between Burgeo Bank (Subdiv. 3Ps) and the Gulf (Subdiv. 3Pn and Div. 4R). Trace element analyses of otoliths of maturing females collected on Burgeo Bank in late April were used to determine their stock origin. Otoliths of spawning females from the northern Gulf and Burgeo Bank were used as reference groups. The trace element results indicated that a substantial fraction (41-52\%) of the maturing female cod sampled on Burgeo Bank in late April 2001 originated from the northern Gulf of St. Lawrence stock.
\end{abstract}

Key words: Burgeo Bank, distribution, Gadus morhua, Gulf of St. Lawrence, otoliths, sexual maturity, spawning stock, stock mixing, southern Newfoundland.

\section{Introduction}

Understanding the distribution and migration of exploited fish populations is essential for sound fisheries management. In the northern Gulf of St. Lawrence, Atlantic cod (Gadus morhua) are distributed north of the Laurentian Channel, off Newfoundland's west coast, and along the north shore of Québec (Subdiv. 3Pn and Div. 4RS) (Fig. 1). In the autumn, most of these cod migrate to deep water east of Cabot Strait near the mouth of the
Gulf of St. Lawrence to overwinter. During this time, these fish may intermingle with the cod from the southern Newfoundland stock (Subdiv. 3Ps). Many authors have reported mixing between cod stocks on Burgeo Bank, in the western part of Subdiv. 3Ps (Fig. 1). Tagging (Templeman, 1974; 1979; Lear, MS 1988; Moguedet, 1994; Gascon et al., MS 1990; Bérubé and Fréchet, MS 2001; Brattey et al., MS 2002; Brattey and Healey, MS 2004), parasite (Bishop et al., MS 1988), and meristic studies (Templeman, 1981) suggest that more than one cod stock occurs in Subdiv.

${ }^{1}$ Present address: Alliance Environnement, 337 Boul. La Salle, Baie-Comeau, Quebec, Canada G4Z $2 Z 1$ 


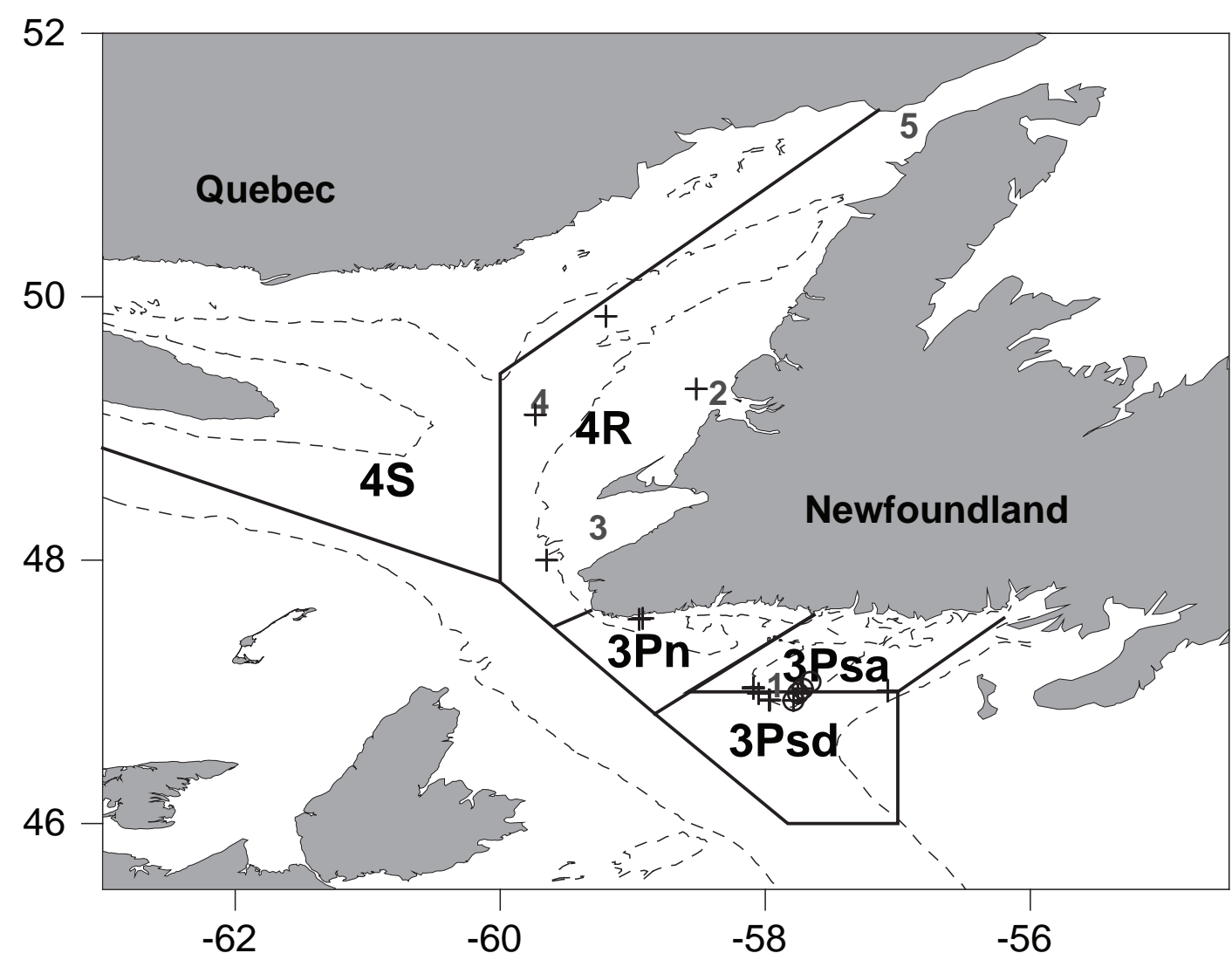

Fig. 1. The Gulf of St. Lawrence, including locations mentioned in the text: 1) Burgeo Bank; 2) Bay of Islands; 3) St. George's Bay; 4) Esquiman Channel; 5) Strait of Belle Isle. Capture locations of unknown (o) and reference $(+)$ samples of female cod (except for 11 otoliths from DFO surveys) used for trace element analysis of otoliths are indicated. The $200 \mathrm{~m}$ isobath is shown.

3Ps during winter. Moreover, movements of northern Gulf cod into Subdiv. 3Ps may extend further east than Burgeo Bank (Bérubé and Fréchet, MS 2001).

In the early 1990s, mixing of the stocks became important as stock abundances declined. Both the northern Gulf and southern Newfoundland cod stocks were placed under fisheries moratoria in the early 1990s. However, when the fisheries reopened in 1997, the quota was set substantially higher in Subdiv. 3Ps than in Subdiv. 3Pn and Div. 4RS. This raised concerns that elevated fishing mortality might occur on the northern Gulf stock when it was mixed with the southern Newfoundland stock (Chouinard, MS 2000). Trawl surveys indicated a shift in the winter distribution of northern Gulf cod to more southerly and easterly areas in the 1990s (Castonguay et al., 1999), which likely increased mixing with the southern Newfoundland stock. Based on trace elements (elemental fingerprints) of otoliths collected in 1996 and 1997, Campana et al. (1999) concluded that up to $75 \%$ of the cod on Burgeo Bank in January were of northern Gulf origin. Based on this finding, the Subdiv. 3Psd area (Fig. 1) has been closed to cod fishing from 15 November to 15 April since 1998 to protect the northern Gulf stock (Chouinard, MS 2000). However, the maturity stage of reference fish was not determined in the Campana et al. (1999) study and it was assumed that cod caught in spring in a given area would be spawning in that area, which may not be the case. Furthermore the stock affinity of cod on Burgeo Bank in April, when the Canadian Department and Fisheries and Oceans carries out the annual research vessel abundance survey, is an important stock mixing question (Shelton et al., MS 1996; Campana et al., 1999) because mixing could bias upwards abundance of Subdiv. 3Ps cod.

The first objective of the present study was to examine the spatio-temporal distribution of spawning cod in the northern Gulf of St. Lawrence (Subdiv. 3Pn and Div. 4RS) and in the neighbouring area of Burgeo Bank (Subdiv. 3Psa and 3Psd) during spring 2001. Our second objective 
was to determine stock origin of maturing fish caught on Burgeo Bank in April 2001 using trace element analysis of otoliths by comparing maturing cod against reference spawning cod from both Subdiv. 3Pn and Div. 4R and the Burgeo Bank region of Subdiv. 3Ps.

\section{Materials and Methods}

\section{Biological Sampling}

Cod were sampled in 2001 in NAFO areas Subdiv. 3Psa, 3Psd, 3Pn, and Div. 4R from the end of April (26-30) to late July (12-25) (Fig. 1). Within each area, the sexual maturity of females was determined. The study was restricted to females as it is more difficult to visually distinguish maturity stages in male gadoids (Templeman et al., 1978). Furthermore, males seem to be ready to reproduce earlier in the season (Brawn, 1961), and sexual maturity is maintained over a longer period than females (Hutchings and Myers, 1993; Morgan and Trippel, 1996). Thus, the analysis of female maturity stages was considered to more accurately reflect the period and location where cod eggs would actually be released.

Fish were collected with a Rock Hopper bottom trawl directed with a sounder, except in Subdiv. 3Pn where longlines were used and in Div. 4R in July, where feathered hooks and gillnets were used because the bottom trawl gear did not collect enough samples (Fig. 2). Only fish with fork length $\geq 40 \mathrm{~cm}$ were sampled to ensure a sufficient proportion of mature females. Fish were kept on ice and dissections performed within 1 to 2 days following capture to ensure the accurate determination of maturity stages and gonad freshness for tissue sampling (histology). Fork length ( $\pm 1 \mathrm{~mm})$ and total weight $( \pm 1 \mathrm{~g})$ were measured from each fish. Sexual maturity of each female was evaluated by visual examination of the gonads using a four-stage classification: immature, maturing, spawning, and spent (Morrison, 1990). The criteria used to determine maturity stage were: 1) immature-no eggs visible, small and firm ovaries; 2) maturing-opaque eggs visible to the naked eye; 3) spawning-presence of translucent (hydrated) eggs; and 4) spent-ovaries soft and flabby, with a whitish or bluish color. A transverse cut was made through the ovary of each maturing fish to ascertain the absence of translucent eggs remaining in the middle of the ovary, indicating previous spawning.

To validate the visual determination of maturity stages, subsamples of ovaries classified as maturing, spawning, or spent were preserved in $4 \%$ formaldehyde for histological analysis. From these subsampled females, otoliths were also extracted for elemental fingerprint analysis.

\section{Histological Analysis}

Ovaries preserved in formaldehyde were embedded in paraffin and transverse sections $(5 \mu \mathrm{m})$ were stained with haematoxylin/eosin. The stage of the most advanced oocytes and the presence of post-ovulatory follicles (POF) were detected using a stereomicroscope and then recorded. For gonads visually classified as spent, five measurements of ovarian wall thickness were taken in areas free of blood vessels.

Maturity was recorded as: 1) immature-small oocytes with no vitellus, thin ovarian wall; 2) maturingvitellogenic oocytes; 3) spawning-hyalin oocytes and/or POF; or 4) spent-POF (some remnant hyalin oocytes could be present), thick ovarian wall (e.g., Kjesbu and Kryvi, 1989; Morrisson, 1990). Histological evaluations of maturity were conducted without reference to the macroscopic maturity stage determinations.

\section{Data Analysis}

Contingency tables and G-tests for goodness of fit were used to compare the relative distribution of sexual maturity stages between samples within each area during each month and between areas for each month. A posteriori tests using the Bonferroni z statistic (Legendre and Legendre, 1983, adapted from Neu et al., 1974) were used to detect differences between observed and expected percentages for the maturity stages. Samples from Subdiv. 3Pn were included in the analysis even though the Subdiv. 3Pn samples were collected using longline rather than bottom trawl gear. Furthermore, median fork length has been compared between areas using the non-parametric Kruskal-Wallis test.

\section{Trace Element Analysis of Otoliths}

Otoliths from 70 spawning-stage females from Subdiv. 3Pn and Div. 4R and 36 spawning-stage females from Burgeo Bank (in both Subdiv. 3Psa and 3Psd) collected in May and June as part of this study were used as reference groups. To obtain a suitable sample size in Subdiv. 3Ps, some (31\%; 11 out of 36 otoliths) of the Burgeo Bank reference otoliths of spawning-stage females were obtained from research vessel surveys carried out by the Department of Fisheries and Oceans (DFO) in April 2000 (2 otoliths), 2001 (5 otoliths), and 2002 (4 otoliths). Campana et al. (2000) found no significant difference between reference samples separated by a period of two or three years, indicating that including reference samples from 2000 and 2002 was appropriate here. The maturity stage of each reference fish was determined histologically, except for the 11 fish obtained from the DFO research vessel surveys in Subdiv. 3Ps. Reference samples were used to attribute a stock origin to two unknown samples of 23 and 32 maturing female cod caught in the mixing zone 

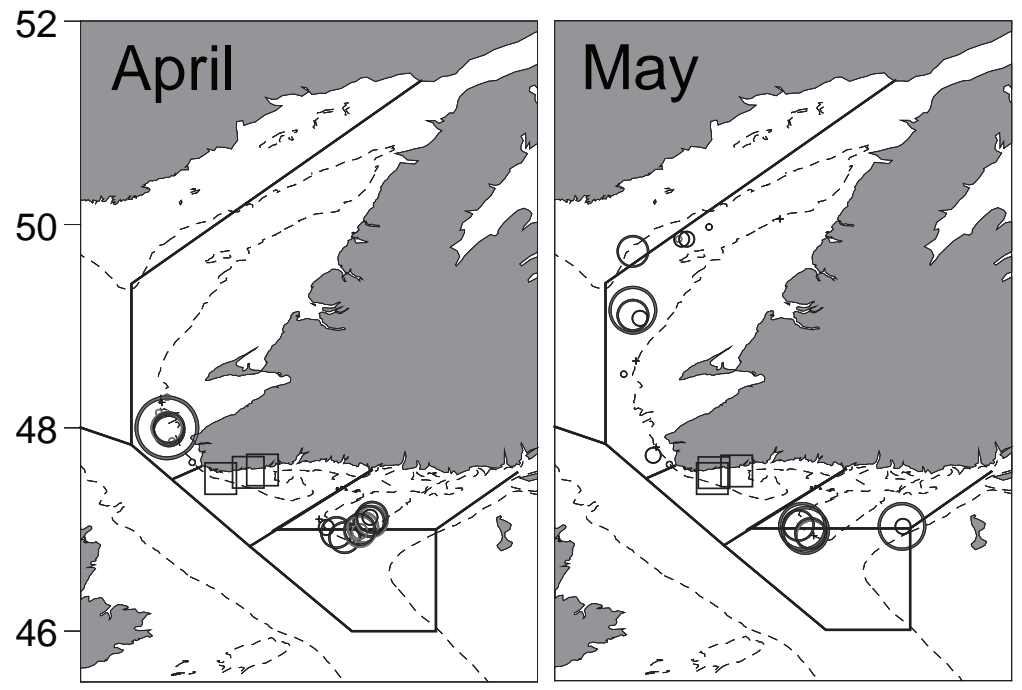

\section{Trawl catch rates $(\mathrm{kg} / \mathrm{h})$}
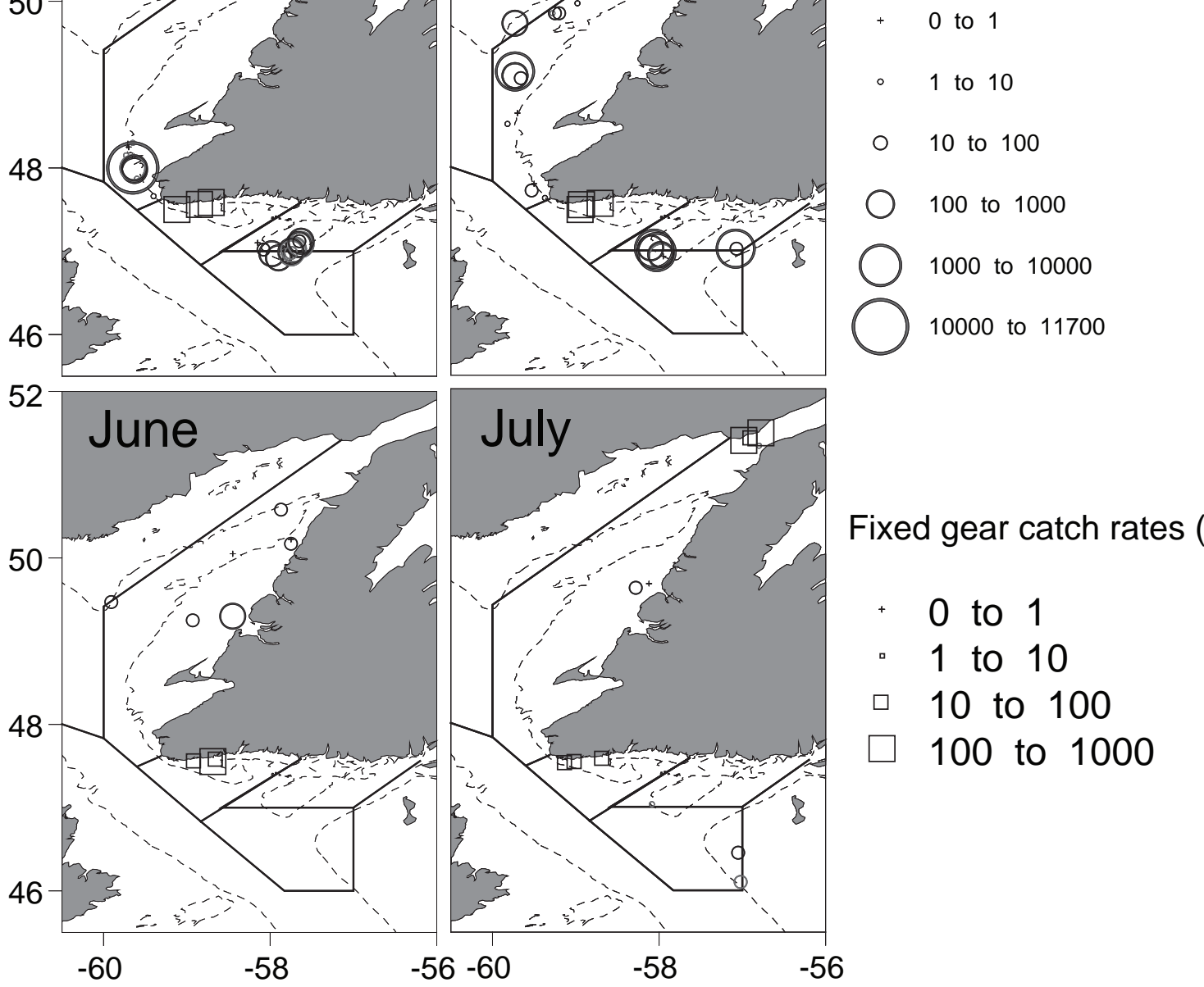

Fixed gear catch rates (kg/trip)

Fig. 2. Trawl (circles) and fixed gear (squares) catch rates in the four areas (Div. 4R, Subdiv. 3Pn, 3Psa, and 3Psd) for the four months of the study. The fixed gear was longlines in Subdiv. 3Pn and gillnets and feathered hooks in northern 4R.

(Subdiv. 3Psa and 3Psd) on 26 April 2001 as part of this study. These unknown samples are only a small fraction of the maturing females collected in Subdiv. 3Ps in April (180 fish) and in May 2001 (145 fish). Capture locations of unknown and reference samples are shown on Fig. 1.

Otolith trace element composition (Ba, Li, Mg, Mn, and $\mathrm{Sr}$ ) was determined using isotope dilution inductively coupled plasma mass spectrometry (ID-ICPMS). The effect of otolith weight had to be removed from the $\mathrm{Li}$ concentration prior to statistical analysis. The classification of unknown samples collected on Burgeo Bank was performed using a refined version of the Integrated Stock Mixture Analysis software (ISMA) (Campana et al. 1999; 2000). ISMA is a maximum likelihood-based technique, which can be used to estimate the stock composition of an unknown stock mixture from trace elements of otoliths using reference groups of known identity. ISMA can also simultaneously analyze trace elements of otoliths, microsatellite DNA, and vertebral count (see Chouinard, MS 2000).

\section{Results}

\section{Distribution of Catch Rates}

Catch rates of cod varied over the study period. In all areas, the highest commercial catch rates occurred in April and May (Fig. 2). Both commercial and survey catch rates dropped precipitously in June in Div. 4R and Subdiv. 3Pn (Fig. 2 and 3). Bad weather prevented any survey activity 

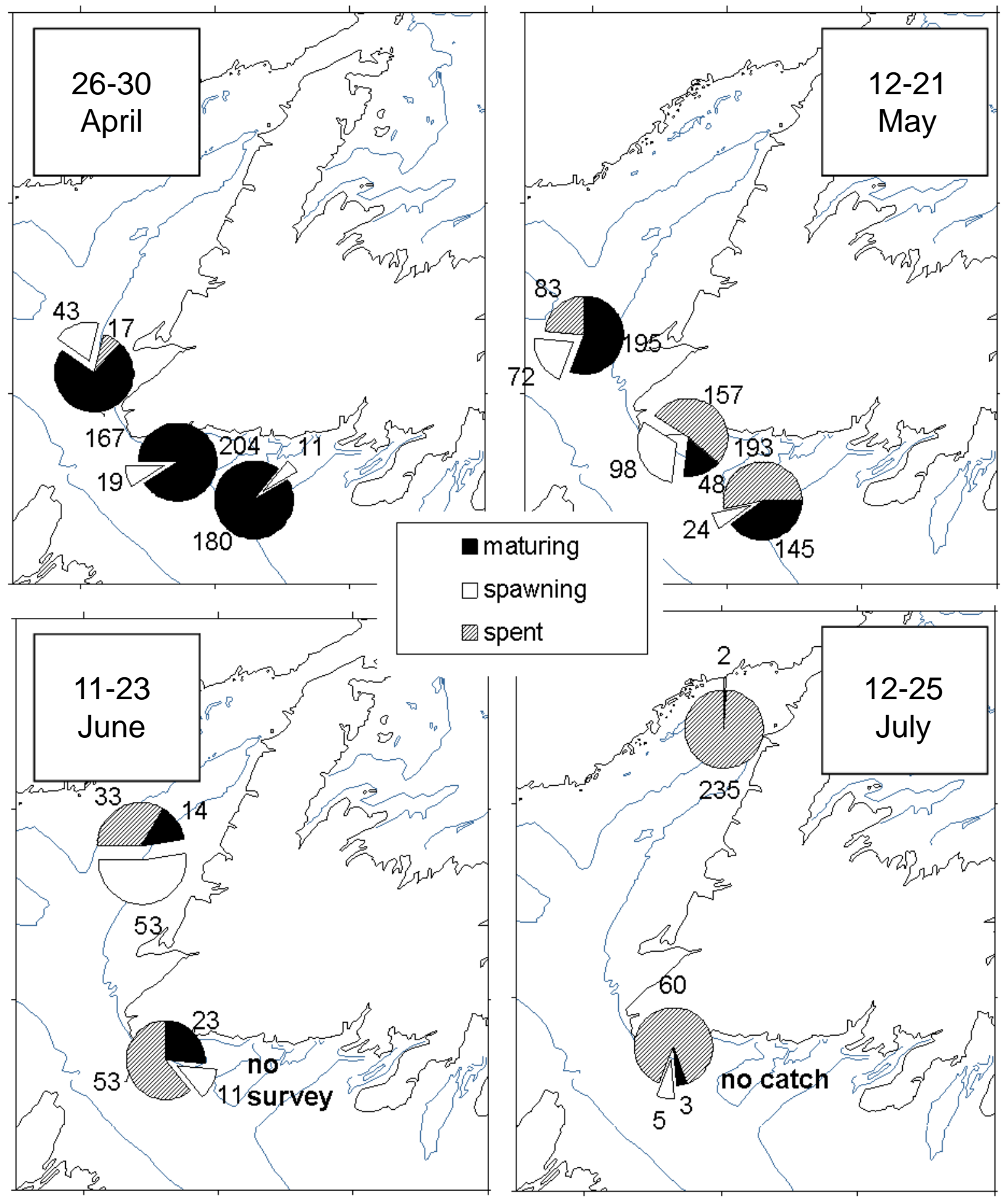

spent

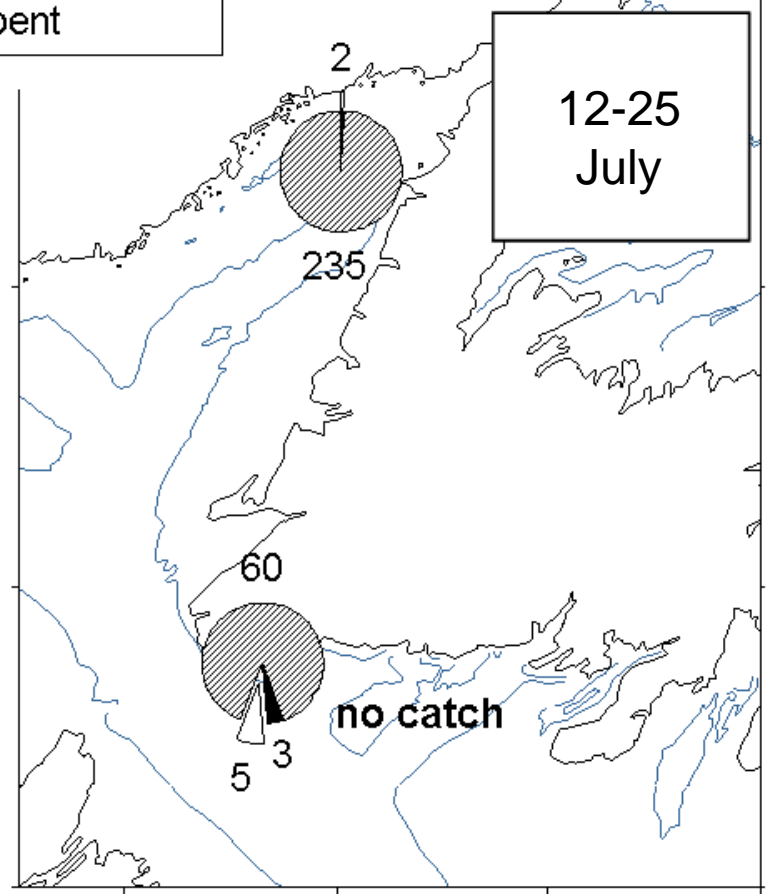

Fig. 3. Sexual maturity stages of adult female cod in Div. 4R, Subdiv. 3Pn, and on Burgeo Bank from April to July 2001. Sample size of each maturity stage is shown. There was no survey on Burgeo Bank in June. There was a survey on Burgeo Bank in July but no fish were caught.

in Subdiv. 3Ps in that month. Burgeo Bank was surveyed at the beginning of July, but no cod were taken. Catch rates in Subdiv. 3Pn were also low in July.
In Div. 4R, the largest commercial catch rates of cod occurred at the mouth of St. George's Bay in April and in the deep waters (>250 m) of the Esquiman Channel in 
May. In June, the largest catch rates were made close to Bay of Islands while in July the highest catch rates occurred inshore in the Strait of Belle Isle (see Fig. 1).

\section{Sexual Maturity Composition}

Visual determinations of sexual maturity stage were accomplished for 2129 female cod from the 6141 individual fish $\geq 40 \mathrm{~cm}$ collected during the April-July 2001 study period (Table 1). Because fish $<40 \mathrm{~cm}$ were excluded, length distributions were not normal. Hence medians are shown in Table 1 instead of means. The gonads of 450 females were analyzed histologically to validate the use of the macroscopic evaluation of maturity stages. Only a small percentage of females identified macroscopically as maturing or spawning were reclassified following histology (4.5\% and 3.8\%, respectively). However, 14\% of spent females were reclassified as immature following histological examination. Given the good correspondence between the visual and histological determinations of sexual maturity for maturing and spawning fish, the macroscopic determinations of maturity stages were used in the analyses.

Relative frequencies of maturity stages in adult females varied temporally and spatially (Fig. 3 and 4). In Div. 4R, the proportion of spawning females increased monthly between April and June (19 to 53\%) (Fig. 4). In Subdiv. 3Pn, the percentage of spawning females was low in April (9\%), high in May (32\%), and low again in June (7\%). Very few spawning females (39) were caught on Burgeo Bank (Subdiv. 3Psa and 3Psd) in April and May and the proportion of spawning females was only between 6 and $7 \%$ in both months.

Female maturity stage percentages differed significantly between areas in April (G-test, $P<0.001$ ) (Table 2). A higher percentage of spawning females (19\%) occurred in 4R than in other areas (6-9\%) and spent females were only found in Div. 4R. In May, the percentage of maturing females decreased in all areas while the proportion of spent females increased (Fig. 4). Significant differences (G-test, $P<0.001)$ in maturity stage frequencies were detected between all of the areas sampled in both May and June (Table 2). In July, nearly all of the females collected in Div. 4R and Subdiv. 3Pn were spent.

\section{Length Frequencies and Maturity at Size}

Monthly length frequency distributions of cod varied during the study (see median lengths in Table 1). In April, the median size of cod in Div. 4R was smaller than in the other areas (Kruskal-Wallis test, $P<0.001$ ), while in May the median size of fish was lowest on Burgeo Bank (Kruskal-Wallis test, $P<0.001$ ). In all areas, sampling was limited to cod larger than $40 \mathrm{~cm}$. Comparisons of length frequencies were not conducted for cod collected in Subdiv. 3Pn or for Div. 4R cod obtained in July, as these fish were not collected with the survey bottom trawl gear used in other areas and months.

The maturation pattern of female cod collected in Div. 4R was different than in the other areas (Fig. 5; Table 3). Females in Div. 4R had a higher percentage of mature fish

TABLE 1. Median and range of fork length $(\mathrm{cm})$ of $\operatorname{cod} \geq 40 \mathrm{~cm}$ for the different areas and months. Sample size of all fish (including immature fish and males) is also shown (N).

\begin{tabular}{llcccc}
\hline \hline Area & Parameter & April & May & June & July \\
\hline Div. 4R & Median & 46.6 & 50.8 & 52.7 & 49.3 \\
& Range & $40.0-93.0$ & $40.0-81.1$ & $40.2-82.9$ & $39.8-75.7$ \\
& N & 693 & 687 & 325 & 556 \\
Subdiv. 3Pn & Median & 56.4 & 55.7 & 56.0 & 54.2 \\
& Range & $40.0-89.7$ & $40.1-75.4$ & $40.4-104.5$ & $40.2-83.2$ \\
& N & 745 & 648 & 224 & 173 \\
Subdiv. 3Psa & Median & 53.0 & 48.0 & - & - \\
& Range & $40.0-98.0$ & $40.0-76.4$ & - & - \\
& N & 402 & 651 & - & - \\
Subdiv. 3Psd & Median & 54.5 & 47.4 & - & - \\
& Range & $40.5-110.0$ & $40.0-81.8$ & - & - \\
& N & 396 & 641 & - & - \\
\hline
\end{tabular}




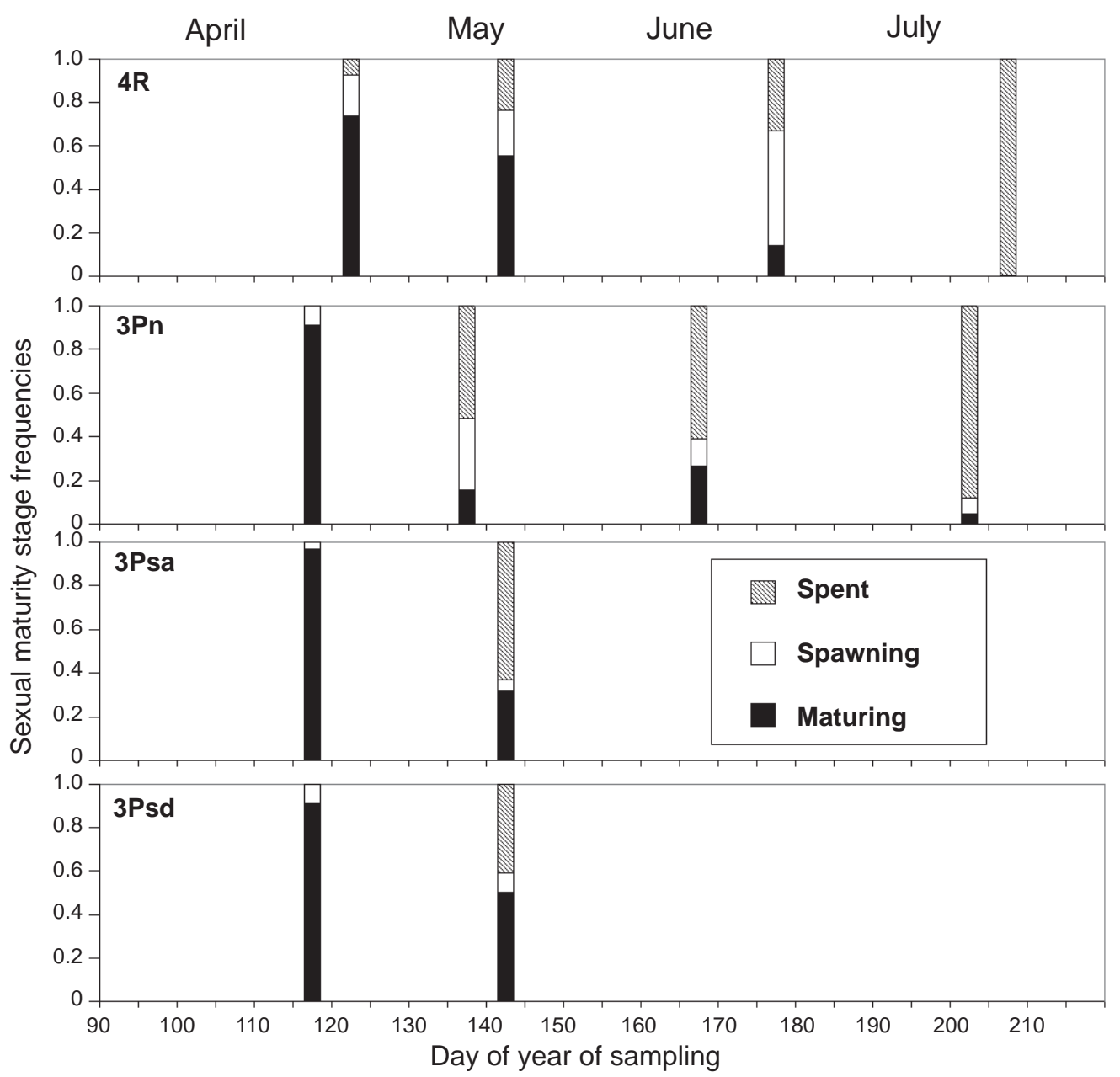

Fig. 4. Seasonal evolution of relative frequency of the different maturity stages in adult female cod.

TABLE 2. Number of adult females of each maturity stage sampled per month and per area. Percentages are shown in parenthesis. Bolded percentages differ from expected values, according to $\mathrm{G}$ tests followed by $a$ posteriori Bonferroni $\mathrm{z}$ tests comparing the frequency distribution of maturity stages between areas for each month.

\begin{tabular}{|c|c|c|c|c|c|}
\hline & & Maturing & Spawning & Spent & Total \\
\hline \multirow[t]{4}{*}{ April } & Div. 4R & 167 (74\%) & 43 (19\%) & 17 (7\%) & 227 \\
\hline & Subdiv. 3Pn & 205 (92\%) & 19 (8\%) & $0(0 \%)$ & 224 \\
\hline & Subdiv. 3Psa & 100 (97\%) & 3 (3\%) & $0(0 \%)$ & 103 \\
\hline & Subdiv. 3Psd & 80 (91\%) & $8(9 \%)$ & $0(0 \%)$ & 88 \\
\hline \multirow[t]{4}{*}{ May } & Div. 4R & 195 (56\%) & 72 (21\%) & 83 (24\%) & 350 \\
\hline & Subdiv. 3Pn & 48 (16\%) & 98 (32\%) & 157 (52\%) & 303 \\
\hline & Subdiv. 3Psa & 64 (32\%) & 10 (5\%) & $127(63 \%)$ & 201 \\
\hline & Subdiv. 3Psd & 81 (50\%) & 14 (9\%) & 66 (41\%) & 161 \\
\hline \multirow[t]{2}{*}{ June } & Div. 4R & $14(14 \%)$ & $53(53 \%)$ & 33 (33\%) & 100 \\
\hline & Subdiv. 3Pn & 23 (26\%) & $11(\mathbf{1 3 \%})$ & 53 (61\%) & 87 \\
\hline \multirow[t]{2}{*}{ July } & Div. 4R & $0(0 \%)$ & 2 (1\%) & 235 (99\%) & 237 \\
\hline & Subdiv. 3Pn & $3(4 \%)$ & $5(7 \%)$ & 60 (88\%) & 68 \\
\hline
\end{tabular}




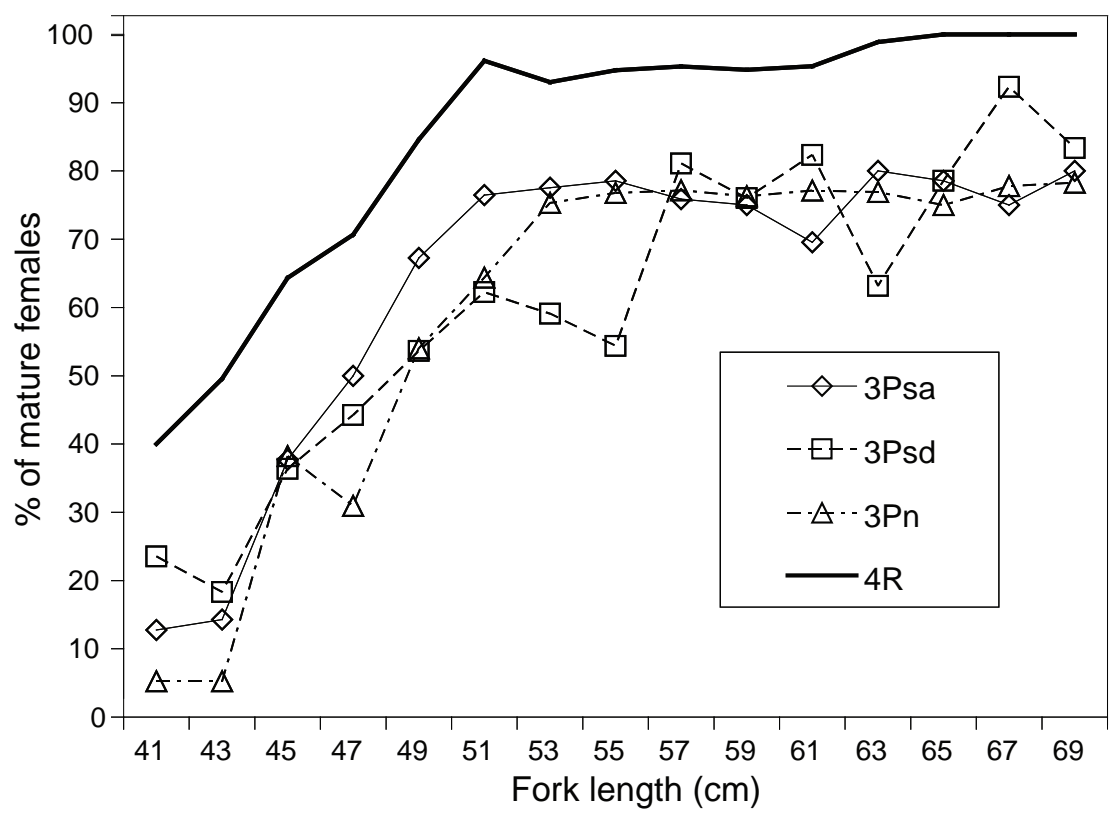

Fig. 5. Percentage of mature fish by length-class for female cod in the northern Gulf of St. Lawrence (Subdiv. 3Pn and Div. 4R) and on Burgeo Bank (Subdiv. 3Psa and 3Psd).

TABLE 3. Number of female cod of each maturity stage sampled in each area per size class, all months combined.

\begin{tabular}{|c|c|c|c|c|c|c|c|}
\hline & \multicolumn{7}{|c|}{ Fork length (cm) } \\
\hline & & $>40-50$ & $>50-60$ & $>60-70$ & $>70-80$ & $>80-90$ & $>90$ \\
\hline \multirow[t]{4}{*}{ Div. 4R } & immature & 208 & 21 & 3 & - & - & - \\
\hline & maturing & 188 & 155 & 29 & 4 & - & - \\
\hline & spawning & 58 & 78 & 28 & 3 & 2 & 1 \\
\hline & spent & 119 & 164 & 76 & 8 & 1 & - \\
\hline \multirow[t]{4}{*}{ Subdiv. 3Pn } & immature & 133 & 115 & 59 & 13 & 3 & - \\
\hline & maturing & 33 & 145 & 70 & 25 & 5 & 1 \\
\hline & spawning & 3 & 71 & 40 & 13 & 4 & 2 \\
\hline & spent & 24 & 142 & 75 & 11 & 15 & 3 \\
\hline \multirow[t]{4}{*}{ Subdiv. 3Psa } & immature & 175 & 45 & 13 & 4 & 3 & - \\
\hline & maturing & 47 & 77 & 32 & 4 & 3 & 1 \\
\hline & spawning & 8 & 5 & - & - & - & - \\
\hline & spent & 54 & 56 & 17 & - & - & - \\
\hline \multirow[t]{4}{*}{ Subdiv. 3Psd } & immature & 177 & 55 & 13 & 7 & 1 & 1 \\
\hline & maturing & 59 & 72 & 21 & 4 & 3 & 2 \\
\hline & spawning & 8 & 7 & 3 & 2 & & 2 \\
\hline & spent & 23 & 28 & 12 & 2 & 1 & - \\
\hline
\end{tabular}


at smaller sizes $(41-50 \mathrm{~cm})$ than females in Subdiv. 3Pn or 3Ps. As well, more than $90 \%$ of the Div. 4R females that were $50 \mathrm{~cm}$ and larger were mature, while females in the other areas exhibited much lower maturation rates (70-80\%) at larger sizes.

\section{Trace Element Analysis of Otoliths}

The classification (ISMA) of maturing female cod from Burgeo Bank in late April 2001 using spawning female cod in Div. 4R, Subdiv. 3Pn, and Burgeo Bank as reference groups indicated that a substantial proportion of the Burgeo Bank fish had trace element compositions characteristic of the northern Gulf of Lawrence (Subdiv. 3Pn and Div. 4RS) cod stock. Trace element analyses indicated that 52 and $41 \%$ of the small samples $(n=23$ and $n=32$, respectively) of maturing female cod obtained from two trawl sets conducted in areas Subdiv. 3Psa and 3Psd on Burgeo Bank were of Subdiv. 3Pn and Div. 4RS origin.

\section{Discussion}

Stock identification problems are common in marine fisheries, and many cod stocks intermingle. In Iceland, Hovgård and Christensen (1990) used tagging to distinguish between cod of inshore and offshore origin. Rätz (1994) identified two cod stocks with different geographic origins (east and west) in Greenland using otolith type. Templeman (1974; 1979; 1981) conducted large-scale studies in Northwest Atlantic waters to discriminate among several cod stocks using tagging and vertebral number. Campana et al. (1999) was able to discriminate among several cod stocks found in the same area using otolith elemental fingerprints. The current study used maturity stage composition and trace element fingerprints (based on spawning fish of known origin) to examine mixing between different cod stocks.

On Burgeo Bank in late April 2001, reproduction had already begun as a small percentage (6\%) of the females collected were in spawning condition, although no spent females were found. Females on Burgeo Bank appeared to be in a less advanced stage of reproduction than those sampled in April in the northern Gulf (Div. 4R), where $19 \%$ of the females were in spawning condition and $7 \%$ were spent. A few weeks later in mid-May, a small proportion (7\%) of spawning females was still observed on Burgeo Bank, but 53\% of the adult females were spent. However, the area where these fish spawned is unknown. Since the average spawning period of a female cod lasts between 25 and 55 days (Hutchings and Myers, 1993; Chambers and Waiwood, 1996; Kjesbu et al., 1996; Fordham and Trippel, 1999; Lambert and Dutil, 2000), it is unlikely that these spent females came from the group of fish dominated by maturing females at the end of April on Burgeo Bank. Unfortunately, no survey was possible on Burgeo Bank in June, and despite a thorough survey search along the offshore part of the Bank in early July, no significant catches of cod were obtained. This suggests that the Burgeo Bank spawners left the area.

The spawning area for the high number (180 fish) and proportion (94\%) of maturing females sampled in April on Burgeo Bank (Subdiv. 3Psa and 3Psd) is also unknown. However, between April and May, the percentage of maturing fish in Subdiv. 3Ps markedly declined (94\% to $40 \%$ ) suggesting that these maturing females left the area to spawn elsewhere as the percentage of female spawners on Burgeo Bank in May was nearly identical to that in April (7\% vs 6\%). The otolith trace element analysis results indicate that a substantial fraction (41-52\%) of maturing fish caught in late April on Burgeo Bank were northern Gulf fish.

The Canadian Department of Fisheries and Oceans annually conducts a research vessel trawl survey in April to estimate the abundance of the southern Newfoundland (Subdiv. 3Ps) cod stock. Mixing of northern Gulf cod in Subdiv. 3Ps at that time of year may bias this estimation upwards (Shelton et al., MS 1996; Campana et al., 1999). Brattey et al. (MS 2002) indicated that between 25 and $67 \%$ of the cod tagged in April on Burgeo Bank were recaptured in the Subdiv. 3Pn and Div. 4RS stock area. Brattey and Healey (MS 2004) found that northern Gulf cod may be found on Burgeo Bank until mid-April and pointed out that the exploitation rate of cod tagged on Burgeo Bank decreased substantially in 2003, mainly due to the closure of the cod fishery in the northern Gulf on that year. Conversely, Bérubé and Fréchet (MS 2001) reported that $22 \%, 12 \%$ and $4 \%$ of cod tagged in Subdiv. 3Pn, Div. 4R, and 4S in summer and autumn were recaptured in Subdiv. 3Ps, respectively. All these studies indicate mixing of northern Gulf cod in Subdiv. 3Ps during winter and spring, and that a variable proportion of the cod present on Burgeo Bank through late April will be fish of northern Gulf origin.

Differences in the trace element composition of otoliths among groups of fish are due to differences in environmental exposure history, and thus do not necessarily reflect genetic identity (Campana, 1999). However, as otoliths are metabolically inert, their elemental composition can serve as a reliable natural tag to track groups of fish over short time periods because otolith size and composition do not appreciably change in the short-term. Once the elemental composition of all potential source groups has been determined, fish remain identifiable as to their source group until subsequent otolith growth 
significantly alters the overall elemental signature. In this type of application, the cause of differences in elemental composition among source groups is irrelevant. On this basis, Campana et al. (1999) concluded that up to $75 \%$ of the cod on Burgeo Bank in January were of northern Gulf origin. However, Campana et al. (1999) assumed that cod caught in spring on Burgeo Bank (the reference group) were indeed spawning there, without considering maturity stage. The current study repeats this analysis more rigorously, by defining the Burgeo Bank reference group as including only those fish in spawning condition on the Bank.

Significant differences in the relative proportion of the maturity stages were detected between areas in the present study. At the beginning of the spring 2001 spawning season, similar maturity stage frequency distributions were observed for female cod in Subdiv. 3Pn and 3Ps whereas distributions for Div. 4R were distinct, showing higher proportions of spawning and spent females. In April 2001, spent females were found only in Div. 4R. Similar proportions of spawning and spent females as found in this study were observed by Ouellet et al. (1997).

Despite the presence of some spawning females on Burgeo Bank, this area was not a major spawning area in spring 2001. Spawning females represented only a very small proportion of the catch, and this proportion was smaller than in the other areas in both April and May. Moreover, the maturing females observed in April were not found as maturing or spawning fish in May, which suggests that a fraction of the maturing fish caught on Burgeo Bank in April spawned elsewhere. Even though cod from eastern Subdiv. 3Ps (Placentia Bay) have been observed to spawn early in the year (February) (Bolon and Schneider, MS 1999), there is no evidence from tagging studies of a westward movement of these fish (Brattey et al., MS 2002). Thus, the origin of the spent females collected from Burgeo Bank in May is unknown.

Cod have been observed to concentrate in large aggregations to spawn (Rose, 1993). This is true in the northern Gulf (Ouellet et al., 1997), but spawning also continues as cod disperse northwards in June. The presence of spawning females off Bay of Islands reported here indicates that the spawning area extends further north than the Bay St. George spawning area found by Ouellet et al. (1997). Fish in spawning condition in June have even been reported north of $50^{\circ} \mathrm{N}$, off Daniel's Harbour (Méthot, 2002). Although some commercial fishermen have reported catching spawning cod in July (DFO, 2002), spawning is usually complete by this month except for some large females, which generally spawn for longer time periods (Hutchings and Myers, 1993).
Gear selectivity differences may have influenced the relative proportion of the maturity stages observed in the different areas and months in spring 2001. Size selectivity differs between longlines and bottom trawls, and these differences could affect maturity stage distributions. Bottom trawls also select fish close to the bottom. Thus, the proportion of spawning females could potentially be underestimated from trawl samples, as spawning females tend to be off bottom when releasing their eggs (Brawn, 1961). Moreover, fishing with trawls and sounders target concentrations of fish; this is not necessarily the case with longlines. Differences in maturity stage composition have been found for cod sampled inside and outside of shoals: shoals have a higher proportion of maturing fish whereas isolated fish outside shoals are of all maturity stages (Ouellet et al., 1997). Laboratory studies suggest that cod feeding decreases during most of the spawning period (Fordham and Trippel, 1999). Thus, longlines, which catch fish with baited hooks, may be less efficient in catching spawning fish. However, comparable proportions of spawning females were caught with longlines in 3Pn and in trawls in 4R in the present study. Nevertheless, differences in gear selectivity represent an important caveat in comparing maturity results from Subdiv. 3Pn with results from other areas.

The histological analyses highlighted the well-known problem of distinguishing immature fish from spent and recovering females (Morrison, 1990). The presence of post-ovulatory follicles and the thickness of the ovarian wall, which are indicators of previous spawning (Burton et al., 1997), were used to distinguish between spent and immature fish. The percentage of spent females in this study was most likely overestimated using visual identification, as $14 \%$ of spent females were reclassified as immature after histological analysis.

It is important to gain a firm understanding of the year-round geographical ranges of migratory animals. Recent advances in otolith chemistry at a fine scale offer the potential to allow reconstructions of fish migratory patterns (Elsdon and Gillanders, 2003). New methods of tracking fish in the open ocean on time scales of months to years based on ultrasonic or radio transmitters have also shown promising results in monitoring direction, variability, and extent of migrations (Block et al., 2001; Comeau et al., 2002). The new concept of migratory connectivity, developed in the ornithological literature (e.g., Webster et al., 2002; Rubenstein and Hobson, 2004), could provide a useful theoretical framework to evaluate the ecological and evolutionary consequences of fish stock mixing. Migratory connectivity concerns the extent to which individuals from the same reproductive area migrate to the same wintering area and vice-versa. Migratory connectivity will 
be termed weak when individuals from a single breeding population migrate to several overwintering locations spread throughout the non-reproductive range and termed strong when most individuals from a given reproductive area migrate to the same non-reproductive area, with a relatively small proportion of individuals migrating to other winter locations. Migratory connectivity may affect population dynamics, and it may have evolutionary consequences and conservation implications in the case of threatened species (Webster et al., 2002).

In conclusion, this study shows that spawning was more advanced in the northern Gulf of St. Lawrence than on Burgeo Bank in both April and May 2001. The high percentage of maturing females on Burgeo Bank in April and the low proportion of spawning females in April and May suggest that a large proportion of maturing females on Burgeo Bank spawned elsewhere and that the Subdiv. 3Ps region was not a major cod spawning area in 2001. Trace element analyses of otoliths indicate that nearly half of the maturing cod sampled on Burgeo Bank in late April originated from the northern Gulf of St. Lawrence stock.

\section{Acknowledgements}

We thank Jason Spingle, David Decker, and Alain Fréchet for their collaboration and involvement in the study. Philippe Schwab helped with sexual maturity determinations. John Brattey provided otoliths of spawning fish from Burgeo Bank. We are also grateful to the captain and crew of the Lady Christiana, the Ocean Venture and the Ocean Joy and to the fishermen Charlie Riles, Wilfred Munden, John Hardy, Ronald Hardy and Kevin Hardy for their cooperation. The analysis would have been impossible to carry out without the assistance of FFAW technicians Philip Seymour, Bernard Warren, Gerald McDonald, and Loomis Way. We also thank the observer Derek Pool for his precious assistance on board fishing vessels. Laure Devine and Fred Serchuk provided useful comments on an earlier draft.

\section{References}

BÉRUBÉ, M., and A. FRÉCHET. MS 2001. Summary of the northern Gulf sentinel tagging program with emphasis on recaptures from adjacent management units. DFO Can. Sci. Advis. Sec. Res. Doc., No. 2001/002, 24 p.

BISHOP, C. A., W. H. LEAR, J. W. BAIRD, and R. WELLS. MS 1988. Comparison of cod samples from St. Pierre Bank, Burgeo Bank, and Rose Blanche Bank from analysis of meristic characters, average length at age, and prevalence of parasitic nematodes. NAFO SCR Doc., 70, Serial No. N1513, 7 p.
BLOCK, B. A., H. DEWAR, S. B. BLACKWELL, T. D. WILLIAMS, E. D. PRINCE, C. J. FARWELL, A. BOUSTANY, S. L. H. TEO, A. SEITZ, A. WALLI, and D. FUDGE. 2001. Migratory movements, depth preference, and thermal biology of Atlantic bluefin tuna. Science, 293: 1310-1314.

BOLON, A. D., and D. C. SCHNEIDER. MS 1999. Temporal trends in condition, gonadosomatic index and maturity stages of Atlantic cod (Gadus morhua) from northern Placentia Bay (Subdivision 3Ps), Newfoundland, during 1998. DFO Can. Sci. Advis. Sec. Res. Doc., No. 2002/45, $23 \mathrm{p}$.

BRATTEY, J., and B. HEALEY. MS 2004. Exploitation of Atlantic cod (Gadus morhua) in NAFO Subdiv. 3Ps: further updates based on tag returns during 1997-2004. DFO Can. Sci. Advis. Sec. Res. Doc., No. 2004/084, 30 p.

BRATTEY, J., D. R. PORTER, and C. W. GEORGE. MS 2002. Movements of Atlantic cod (Gadus morhua) in NAFO Subdiv. 3Ps and updated estimates of exploitation from tagging experiments in 1997-2002. DFO Can. Sci. Advis. Sec. Res. Doc., No. 2002/097, 27 p.

BRAWN, V. M. 1961. Reproductive behaviour of the cod (Gadus callarias L.). Behaviour, 18: 177-198.

BURTON, M. P. M., R. M. PENNEY, and S. BIDDISCOMBE. 1997. Time course of gametogenesis in Northwest Atlantic cod (Gadus morhua). Can. J. Fish. Aquat. Sci., 54(Suppl. 1): 122-131.

CAMPANA, S. E. 1999. Chemistry and composition of fish otoliths: pathways, mechanisms and applications. Mar. Ecol. Prog. Ser., 188: 263-297.

CAMPANA, S. E., G. A. CHOUINARD, J. M. HANSON, and A. FRÉCHET. 1999. Mixing and migration of overwintering Atlantic cod (Gadus morhua) stocks near the mouth of the Gulf of St. Lawrence. Can. J. Fish. Aquat. Sci., 56: $1873-1881$.

CAMPANA, S. E., G. A. CHOUINARD, J. M. HANSON, A. FRÉCHET, and J. BRATTEY. 2000. Otolith elemental fingerprints as biological tracers of fish stocks. Fish. Res., 46: 343-357.

CASTONGUAY, M., C. ROLLET, A. FRÉCHET, P. GAGNON, D. GILBERT, and J.-C. BRÊTHES. 1999. Distribution change of Atlantic cod (Gadus morhua L.) in the northern Gulf of St. Lawrence in relation to an oceanic cooling. ICES J. Mar. Sci., 56: 333-344.

CHAMBERS, R. C., and K. G. WAIWOOD. 1996. Maternal and seasonal differences in egg sizes and spawning characteristics of captive Atlantic cod, Gadus morhua. Can. J. Fish. Aquat. Sci., 53: 1986-2003.

CHOUINARD, G. MS 2000. Report of the cod mixing workshop. DFO Can. Sci. Advis. Sec. Proc. Ser., No. 2000/27, $19 \mathrm{p}$.

COMEAU, L. A., S. E. CAMPANA, and M. CASTONGUAY. 2002. Automated monitoring of a large-scale cod (Gadus morhua) migration in the open sea. Can. J. Fish. Aquat. Sci., 59: $1845-1850$.

DFO. 2002. Northern Gulf of St. Lawrence cod (3Pn, 4RS) in 2001. DFO Sci. Stock Status Rep., No. A4-01 (2002), $11 \mathrm{p}$.

ELSDON, T. S., and B. M. GILLANDERS. 2003. Reconstruct- 
ing migratory patterns of fish based on environmental influences on otolith chemistry. Rev. Fish Biol. Fish., 13: 219-235.

FORDHAM, S. E., and E. A. TRIPPEL. 1999. Feeding behaviour of cod (Gadus morhua) in relation to spawning. J. Appl. Ichthyol., 15: 1-9.

GASCON, D., M. APARICIO, and B. MERCILLE. MS 1990. Estimation du mélange entre les stocks de morue du Nord du Golfe du Saint-Laurent (Divisions 3Pn4RS) et les stocks adjacents (2J3KL, 3Ps et 4TVn [Janvier-avril]) à partir de résultats de marquage. CAFSAC Res. Doc., No. 61, 25 p.

HOVGÅRD, H., and H. CHRISTENSEN. 1990. Population structure and migration patterns of Atlantic cod (Gadus morhua) in west Greenland waters based on tagging experiments from 1946 to 1964. NAFO Sci. Coun. Studies 14: 45-50.

HUTCHINGS, J. A., and R. A. MYERS. 1993. Effect of age on the seasonality of maturation and spawning of Atlantic cod, Gadus morhua, in the Northwest Atlantic. Can. J. Fish. Aquat. Sci., 50: 2468-2474.

KJESBU, O. S., and H. KRYVI. 1989. Oogenesis in cod, Gadus morhua L., studied by light and electron microscopy. J. Fish Biol., 34: 735-746.

KJESBU, O. S., P. SOLEMDAL, P. BRATLAND, and M. FONN. 1996. Variation in annual egg production in individual captive Atlantic cod (Gadus morhua) Can. J. Fish. Aquat. Sci., 53: 610-620.

LAMBERT, Y., and J.-D. DUTIL. 2000. Energetic consequences of reproduction in Atlantic cod (Gadus morhua) in relation to spawning level of somatic energy reserves. Can. J. Fish. Aquat. Sci., 57: 815-825.

LEAR, W. H. MS 1988. Distribution of recapture of cod tagged on Burgeo Bank during March 1986. NAFO SCR Doc., No. 71, Serial No. N1514, 8 p.

LEGENDRE, L., and P. LEGENDRE. 1983. Numerical ecology. Elsevier Scientific, New York.

MÉTHOT, R., 2002. Évolution saisonnière de la maturité sexuelle des morues franches (Gadus morhua) sur le banc de Burgeo et dans le nord du golfe du St-Laurent. M.Sc. thesis, Université du Québec, Rimouski, Québec .

MOGUEDET, P. 1994. Cod (Gadus morhua) migration in the Gulf of St. Lawrence and area south of Newfoundland. NAFO Sci. Coun. Studies, 22: 71-84.

MORGAN, M. J., and E. A. TRIPPEL. 1996. Skewed sex ratios in spawning shoals of Atlantic cod (Gadus morhua). ICES J. Mar. Sci., 53: 820-826.

MORRISON, C. M. 1990. Histology of the Atlantic cod, Gadus morhua: an atlas. Part three. Reproductive tract. Can. Spec. Publ. Fish. Aquat. Sci., 110: 117 p.

NEU, C. W., C. R. BYERS., and J. M. PEEK. 1974. A technique for analysis of utilisation - availability data. J. Wildl. Manag., 38: 541-545.

OUELLET, P., Y. LAMBERT, and M. CASTONGUAY. 1997. Spawning of Atlantic cod (Gadus morhua) in the northern Gulf of St. Lawrence: a study of adult and egg distributions and characteristics. Can. J. Fish. Aquat. Sci., 54: $198-210$.

RÄTZ, H.-J. 1994. Assessment of the migration of Atlantic cod (Gadus morhua L.) between the stocks off West and East Greenland in 1984-86 by means of otolith typing. J. Northw. Atl. Fish. Sci., 16: 7-18.

ROSE, G. A. 1993. Cod spawning on a migration highway in the north-west Atlantic. Nature, 366: 458-461.

RUBENSTEIN, D. R., and K. A. HOBSON. 2004. From birds to butterflies: animal movement patterns and stable isotopes. Trends Ecol. Evol., 19: 256-263.

SHELTON, P., D. E. STANSBURY, E. F. MURPHY, J. BRATTEY, and G.R. LILLY. MS 1996. An assessment of the cod stock in NAFO Subdivision 3Ps. DFO Atl. Fish. Res. Doc., No. 91, 82 p.

TEMPLEMAN, W. 1974. Migrations and intermingling of Atlantic cod (Gadus morhua) stocks of the Newfoundland area. J. Fish. Res. Board Can., 31: 1073-1092.

1979. Migration and intermingling of stocks of Atlantic cod, Gadus morhua, of the Newfoundland area and adjacent areas from tagging in 1962-66. ICNAF Res. Bull., 14: 5-50.

1981. Vertebral numbers in Atlantic Cod, Gadus morhua, of the Newfoundland and adjacent areas, 1947-71, and their use for delineating cod stocks. J. Northw. Atl. Fish. Sci., 2: 21-45.

TEMPLEMAN, W., V. M. HODDER, and R. WELLS. 1978. Sexual maturity and spawning in haddock, Melanogrammus aeglefinus, of the southern Grand Bank. ICNAF Res. Bull., 13: 53-65.

WEBSTER, M. S., P. P. MARRA, S. M. HAIG, S. BENSCH, and R. T. HOLMES. 2002. Links between worlds: unraveling migratory connectivity. Trends Ecol. Evol., 17: 76-83. 